位の検査結果は，鏡筒と眼軸の平行が保た机て いれば，影響は受けないと思われる。

稿を終えるにあたク, 御指導, 御校閲頂きま
した当教室田沢豊教授, および松田恭一先生, 根本竜司先生に愿くお礼申し上げます。また御 助言を頂きました当大学第一生理学教室二唐東 朔助教授に深謝致します。

\title{
大型弱視鏡の取扱いと検査結果 (実験報告)
}

\section{1. 瞳孔間距離値を変化させた時の眼位}

および両眼視機能検査結果への影響

\section{2. 接眼レンズと角膜間の距離を変化させた時の 眼位検査結果への影響}

\section{中村桂子・田中 晴・沢 ふみ子 (大阪医大)}

1. Influence of an Interpupillary Distance on an Angle of Ocular Deviation and Binocular Vision Measured by Using a Major Amblyoscope

2. Influence of a Distance Between the Eyepiece and the Cornea on an Angle of Ocular Deviation in all Positions of Gaze Measured by Using a Major Amblyoscope

Keiko NAKAMURA, Haru TANAKA and Fumiko SAWA Department of Ophthalmology, Osaka Medical College

緒言

今回, 研究会のテーマとして大型弱視鏡が取 ク上げられ，日常軽視していた器械のセッティ ングと測定值の誤差について実験を行なうこと になつた。実験の内容は協会の設定によク，

I. 瞳孔間距離値を変化させた時の眼位およ び両眼視機能検査結果への影響.
2. 接眼レンズと角膜間の距離を変化させた 時の眼位検査結果への影響.

以上の2項目について実験を行なつた。

実験 1 一瞳孔間距離値を変化させた時の眼位 および両眼視機能検査結果への影響

I 、対象および方法

I. 被検者は正常者6名で，その内分けは男 


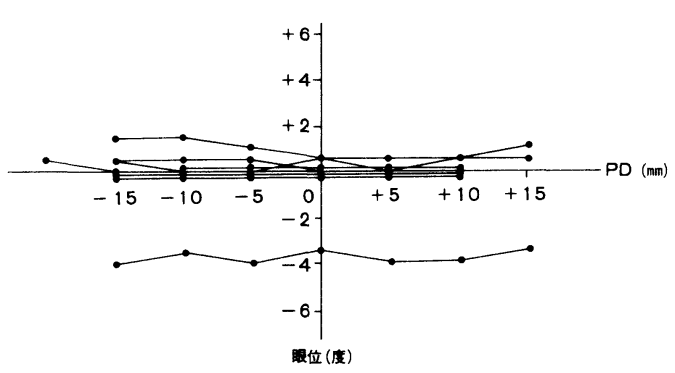

図 1。PDを変化させた時の他賞的斜視角

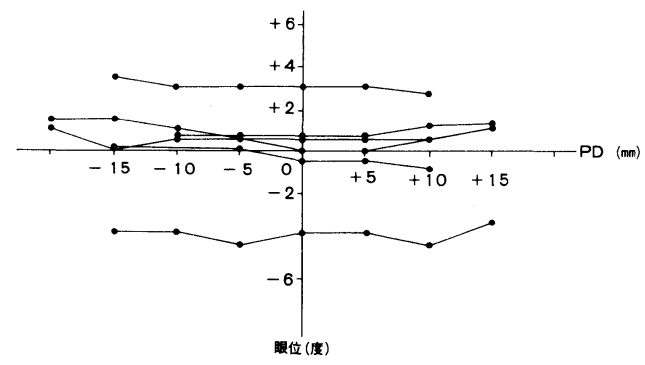

図2，PDを変化させた時の自觉的斜視角

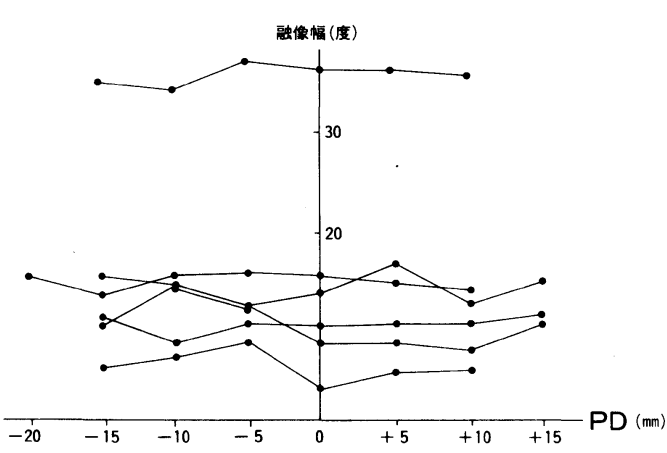

図3，PDを変化させた時の融像幅

2 名, 女4 名。すべて視力は 1.0 以上, 眼位は orth○ないし exophoriaのみで，顕性偏位を有寸る 者は全く含まれていない.

2. 検査項目は，協会の設定によるPDを5

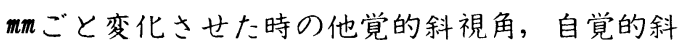
視角, 融像, 立体視の測定である。

3. 斜視角の測定は, 右眼固視にて交代遮閉 法を行なつた。使用器械は Clement Clarke 社の synoptophore 2052 で，スライドは他覚的斜視角

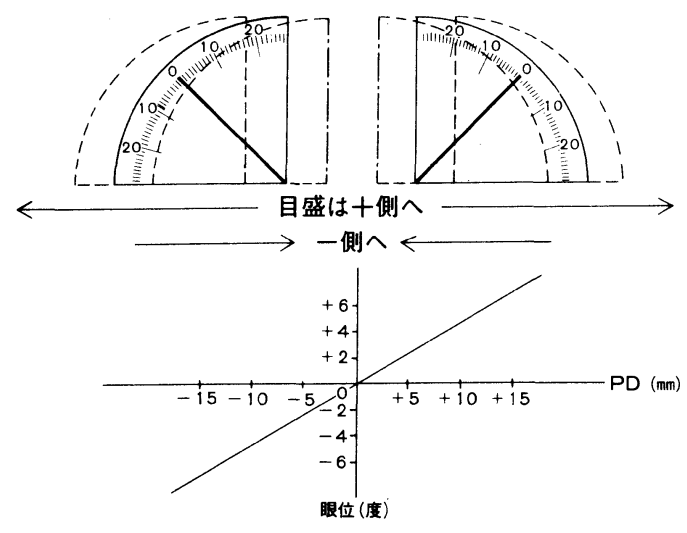

図 4.アームをロツクしたまま PDを変化させた時の 目盛の上でのみかけ上の哭差

・自覚的斜視角にはG47・G 48を, 融像には $F / / 9 \cdot F / 20$ を，立体視にはD $65 \cdot D 66$ を使用した。スライド面の明るさは7にセット して実験を行なつた。

\section{II. 結果}

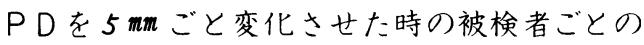
各測定値をグラフに示寸。

1. PDの变化と他覚的斜視角

各々被検者ごとの水平眼位を図/に示してい ろ.垂直偏位は寸べて ${ }^{\circ}$ 以内で, 目立つた変動 を認めなかつたのでグラフでは省略している。 結果はグラフに示されるように，PDを変化さ せても他覚的斜視角には殆ど影響がみられてい ない。

2. PDの变化と自覚的斜視角

他覚的斜視角同様, 被検者ごとの水平眼位を 図2に示している。対象例によつては他覚的斜 視角に比一”，自覚的斜視角が(十)側に出ている 例はあるが, PDの变化に対寸る眼位の変動は みら机ていない。他覚的斜視角同様, 垂直偏位 も寸べて/゚以内の値を示していた。

3. PDの変化と融像幅

被検者ごとの融像幅を図るに示している。対 象例間の視機能の差はもち万んあろが, 各々 dataには大きなララツキは見られない。しかし 自覚的斜視角や他覚的斜視角の dataに比へ，お ずかながらも変動が大きいようにみえるのは， 
融像幅の值には，光学的要素だけでなく感覚的 要素が多分に関与しており, 本人の集中力, 疲 労との関連性も強いということからくると考之 られる。今回の実験の目的から考元ると，この 検査項目は少々不適当であつたように思われる。

4.PDの変化と立体視

立体視の測定結果は, 前述の傾向と同様, P D を変化させても影響がみられなかつた。立体視 においては，視標が foveal slide ではなく，視野 面一杯に広がるバラシュートの視標を使用した

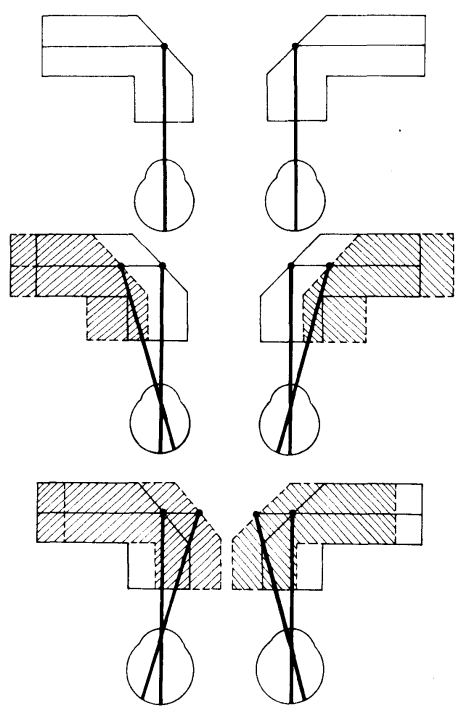

図 5，PDを変化させた時の模式図

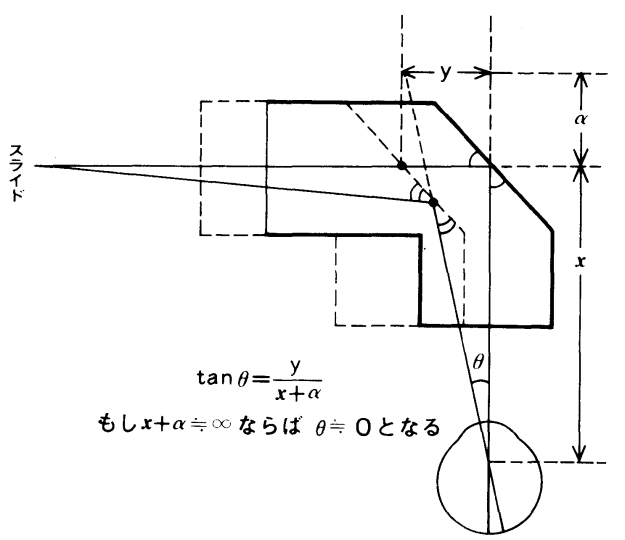

図6.PDを変化させた時の梘線のズレの理論值
ので，実際上の問題点はPDの変化に対忘して スライド面の視野が次けることはないかという 点にあつたのだが，視標が見えずに測定不能と なるケースはなかつた。

5.まとめ

以上の実験結果をまとめると，正常者を対象

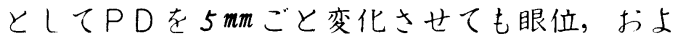
び両眼視機能值は一定であるという結果を得た。

III. 考 按

I. 目盛上でのみかけの誤差について

アームをロックしたままPDを変化させると 目盛かかなり狂うという経験はよくあることと 思う。そのためPDを誤つてセットし検查する と，測定値に誤差が出るのではないかという漠 然とした不安をつい感覚的に抱きや寸い。质こ でまずこの目盛上の誤差について整理してみる ことに寸る．PDを变化させると器械は水平 方向にのみ動く。しかし目盛は円型に目盛つて あるから，ア一ムをこの時ロックしてい机ば当 然目盛は図4の上うに狂つてくろ。PDを広く 寸机は目盛は (十)側入，PDを狭く寸机ば(一) 側へ動く。その時の実際の值は, Clement Clarke

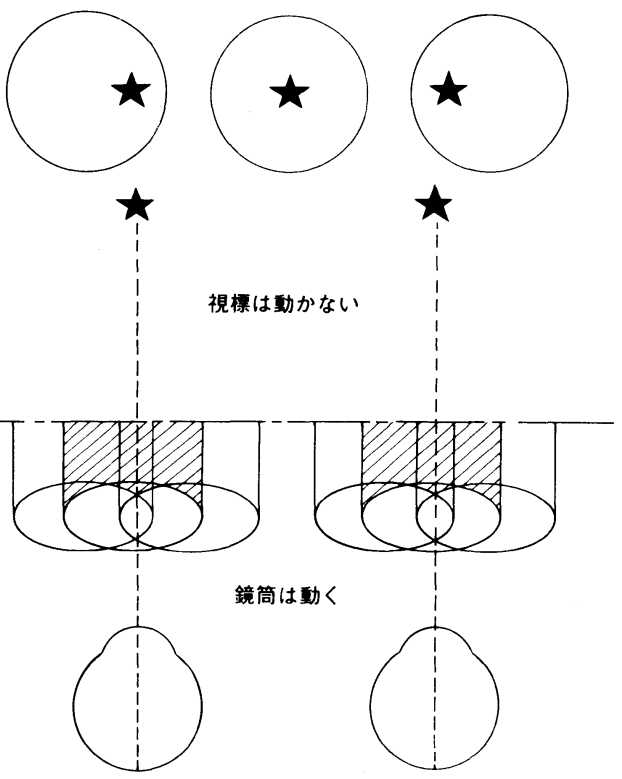

図7。被検者の見え方 
社の synoptophoreではグラフに示すような值とな ろ.

しかし構造上からもわかるように，ア一ムを ロックせずにPDを変化させれば目盛に狂いは 生じない。すなわちこの問題は実際の測定値と の関連性を示しているわけではなく，構造上の みせかけの誤差であることがわかる.

2.PDを变化させた時の視線のズレの理論 的考察

PDを变化させた時の直観的な模式図を図5 に示寸．問題となる視線のズレを $\theta$ と置いて， より詳細にそのズレを図示寸ると図6のように なる。視線のズレ $\theta$ は $\tan \theta=\frac{y}{x+\alpha}$ で求めるこ とができる，問題となるのは接眼レンズから視 標までの長さである。代理店（高田器械）にそ の光学的な構造を問い合わせても明確な答は返 つてきていない。大型弱視鏡の構造上，視標は 遠見視できるように作られているので,一応 Clement Clarke 社の synoptophore S +6.5Dの接眼 レンズが組み込まれており，接眼レンズから視 標までの実測値は/5.4 cmという設計になつて いる。すなわら，接眼レンズから視標までの長 さは無限遠に設定されていることになる。 tan $\theta=\frac{y}{x+\alpha}$ において, $x+\alpha か ゙$ 無限大ならば $\theta=0$

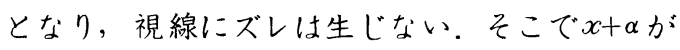
無限大ならば, PDを5m洨变化させてyの 值を变えたところで，その数值は無視できる程 度のものでしかないことになる。

また視線が接眼レンズの光学中心よクズレる ためのレンズのプリズム効果の問題については, 接眼レンズから眼に対しては平行光線となるよ うな構造で作られているので, 無限遠からの平 行光線を視標が視認できる範囲内でどの上うに 位置をかえてみても，プリズム効果はあまり問 題とならない.

\section{3. 被検者の見え方}

図7は，被検者の感想をもとに，実験中の見 え方を図で表したものである。ポイントは，鏡 筒の動きと視標の動きのアンバランスさにある. 被検者は，PDを変化させると鏡筒が大きく動 くのを感じる。しかし，不思議なことに視標は 全く動かないという感想が返つてきた。見え方 は，図の上方に示した円の中に書いているよう
に，鏡筒は動いても視標は動かず，鏡筒の中心 で見ていたものが，PDの変化に㐫じて外側に きたり内側にきたり寸るように見えるだけで視 線をかえているという実感はないという。この ことは，前述の理論的考察を感覚面から裏付け るものと言えそうである。

以上をまとめると，PDを变化させても，遠 見眼位を測定寸るという条件で作られている構 造上, PDを変化させた時の值の変動は, 実際 には微々たるものとなク，視線にズレをつくク 出寸程の影響はないことがわかつた。

実験 2一接眼レンズと角膜間の距離を变化さ せた時の眼位検査結果への影響

\section{I . 対象および方法}

I. 被検者は正常者5名で，その内訳は男2名， 女 3 名。視力, 眼位の状態は実験/の時と同様 である。

2. 検査項目は, 協会の設定により, 眼と接 眼レンズとの距離を5,12, $20 \mathrm{~mm}$ と, 我々が 独自に追加した $30 \mathrm{~mm}$ の4段階に変化させた時 の9方向眼位の測定である。実際には40mm離 した実験も試みたが，ア一ムの回旋点と眼球の 回旋点とのズレが過大となり，注視角が大きい 時に視標が視野内におさまらず，测定不能とな ク今回の報告から省いた。測定した角度は図8

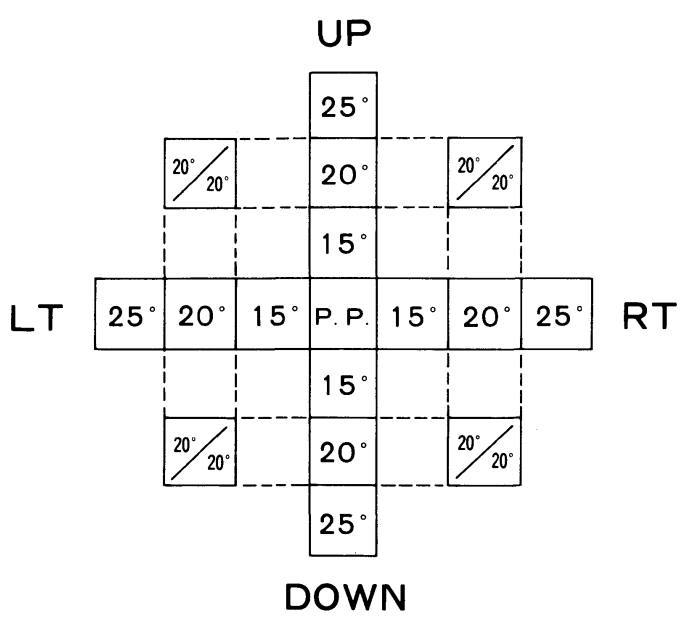

图 8 . 


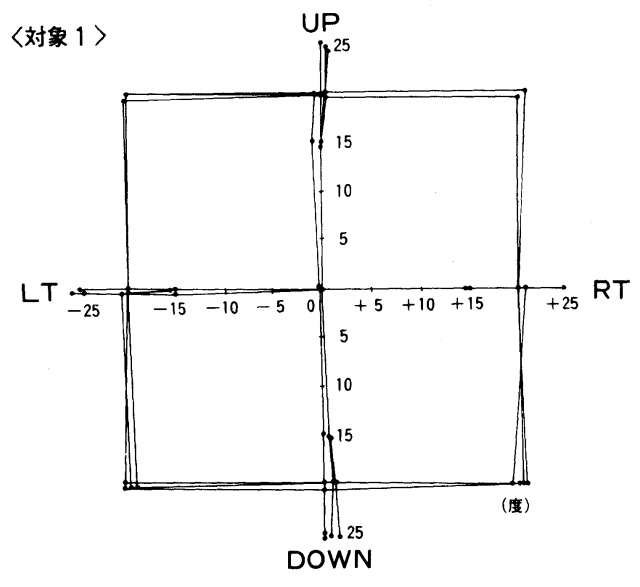

図 9 .

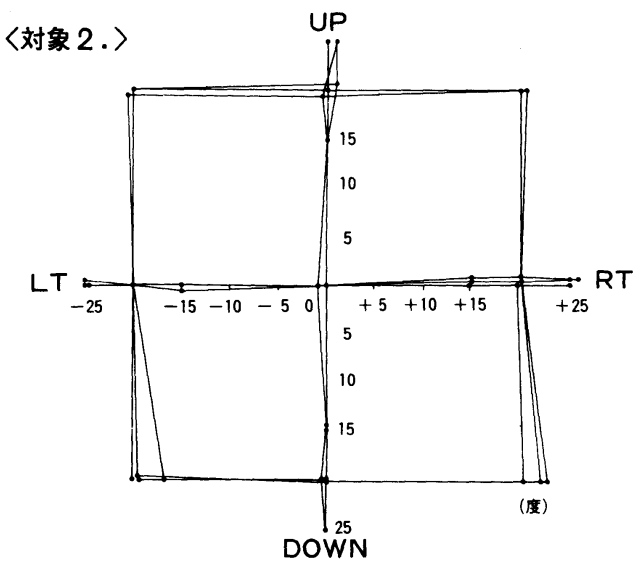

図 10.

で示すとうクである。

3. 斜視角の测定法は, 右眼固視の交代遮閉 法を用いた。原則として他覚的斜視角で測定を 行なつたが，5mmの場合には目と接眼レンズの 間が狭寸ぎて，目の動きが隠さ机てしまい, 他 覚的に観察できず自覚的斜視角の测定へ切り变 えた。使用スライドはA3・A4・G73である。

\section{II. 結果}

対象例ごとに，4段階の測定値を重ね合わせ て困で示した（図9〜/3）. 結果の煩雑さをさ けるため，200動かした場合の9方向眼位のみ

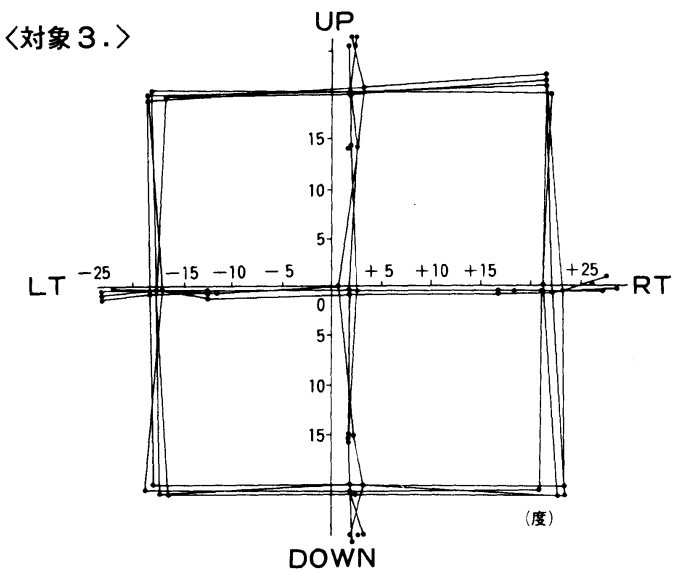

图 11 .

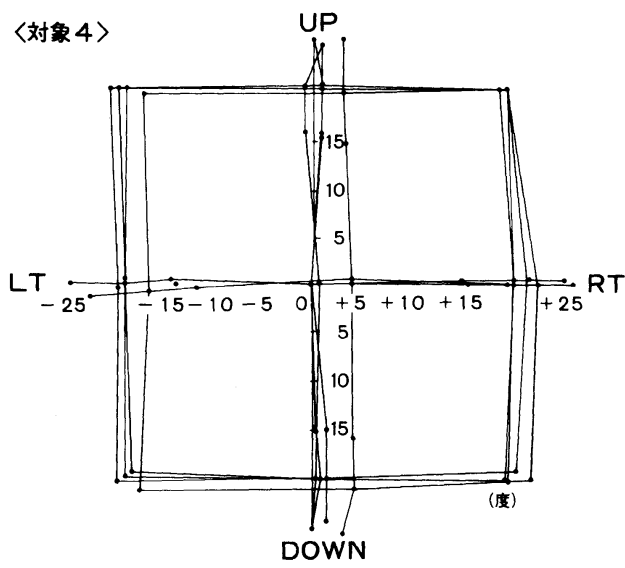

图 12 .

実線で結び，回旋偏位は省略した。

対象/〜3は, 眼と接眼レンズとの距離を変 化させても差が殆どみられていない。一方，対 象 4 〜 は, 自覚的斜視角と他覚的斜視角に差 が出ておク，図をみてもわかるようにひとつ の線だけ（十）側に動いている。このことは測定 值の誤差が大きいことを示しているように読み とれるが，実は自覚と他覚の差であり，今回の 测定目的から考えるとあまり問題とならない.

以上の実験結果をまとめると，眼と接眼レン ズの距離を変化させても9方向眼位の測定値に 影響はみられないという結果を得た。 


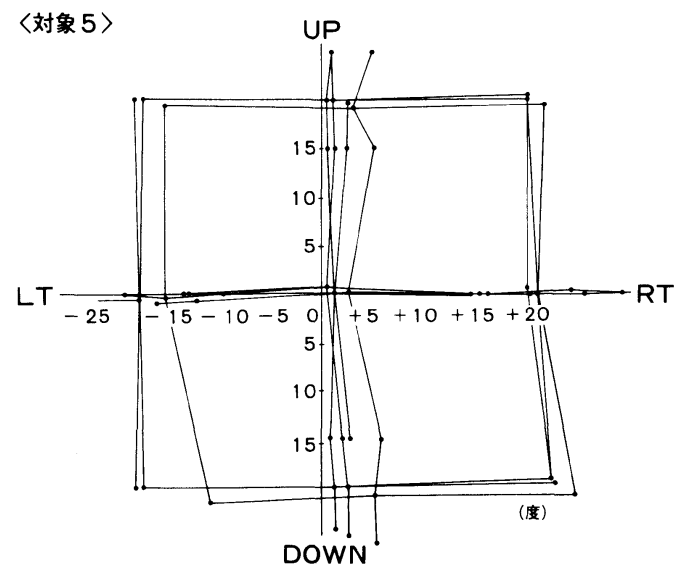

図 13.

\section{III. 考按}

眼と接眼レンズとの距離を変化させた時の測 定值が一定であつた理由を考える。理論上，測 定に誤差が生じないためにはア一ムの回旋点と 眼球の回旋点が一致することが必要となつてく る。両回旋点が一致しておれば，アームをどの 角度に動かしても視軸は正確にアームの動きに 一致し，眼は正確にスライド面を把えることが できる、今回の実験のように，眼と接眼レンズ との距離を変化させると, ア一ムの回旋点と眼 球の回旋点にはおのずからズレが生じてきて, スライド面を把之る角度が変わつてくるように 思わ机る。しかし，実験／と同様，大型弱視鏡 は，接眼レンズから視標までの距離を無限遠と して作られているので，あくまでも無限遠から の平行光線を位置をかえてみているだけにすぎ ないことになる。この実験自体，大型弱視鏡の 視標が視認できる範囲内で距離をかえているだ けなので，その動きは無限遠に対して微々たる ものとなり，接眼レンズと角膜間の距離は測定 値に影響を与える程の factorになり得ない。結
局, 眼と接眼レンズの距離をかえると，測定値 に誤差が生じるのではなく，スライド面の視野 が次るという危俱の方が強いことがわかつた。

\section{要 約}

1. 正常者6名を対象としてPDを5 mmごと に変化させても，眼位および両眼視機能値は一 定であつた。

2. 正常者5名を対象として接眼レンズと角 膜間の距離を5，/2，20，30 mm の4段階に変 化させても，9方向眼位値は一定であつた。

以上が今回正常者を対象として実験を行なつ た結果である。しかし，こ机はあくまでも正常 者の遠見眼位を対象としたものであり，レンズ を負荷して近見眼位の測定を行なう時の問題や， この結果がそのまま斜視患者に適応さ机万もの かどうかという問題は今後の検討課題として残 されている。

最後に, 本研究に対し御支援頂きました東 郁郎教授ならびに直接御指導，御校閲頂きまし た内海隆先生に深謝いたします。また本研究 に御助力頂いた当外来スタッフ，松下清美殿， 内海眼科の視能訓練士, 新居純子殿に厚く扮礼 申し上げます。

翼問 （市立札幌病院）福田雅子 Convergence insuficiencyの患者をシノプトで訓 練する場合，瞳孔間距離を故意に狭くした眼鏡を近用鏡 のみ使用するのと同じように，瞳孔間距離を狭くして行 なうというのは效果的なものでしようか.

答弁 実際には私達はそのような方法で訓練を行なつた 経験がございませんので正確をことは言えませんが，今 回の発表の内容加ら推測しますと, 鏡筒間距離を故意に 変えても被験者側の見え方や測定值には殆ど差はみられ ませんので，お考えになつているような効果は期待でを ないのではないでしようか。 